\title{
Exploration and Practice on the Application-oriented Undergraduate Cultivation System of Electrical Engineering and Automation Specialty under Professional Accreditation
}

\author{
Changchun $\mathrm{Chi}^{1,}$ a and Congjiao Wang ${ }^{1, b}$ \\ ${ }^{1}$ Department of Electrical Engineering Shanghai Dianji University Shanghai 200240 China \\ achicc@sdju.edu.cn, ${ }^{b}$ wangcj@sdju.edu.cn
}

Keywords: Application-oriented undergraduate; Professional accreditation; Talent cultivation system; Evaluation system

\begin{abstract}
Engineering education professional accreditation is a universal guarantee mechanism for the quality of engineering education. It is also the basic of international mutual recognition of the engineering education and engineer qualifications. This article explores the professional accreditation of electrical engineering and automation specialty in Shanghai DianJi University, with in-depth research in the training objectives, graduation requirements, curriculum system, practical aspects and evaluation system. Emphasizing on the development of technical ability and application capability, it aims to practically improve the education quality of application-oriented undergraduate education system of electrical engineering and automation specialty.
\end{abstract}

\section{Engineering Education Professional Accreditation}

Engineering Education Professional Certification, which was initiated by 7 United States professional academies in 1932, refers to the specialized certification of engineering professional education for higher education institutes by the professional certification organizations. It is carried out by specialist guilds, professional associations, education and enterprise experts, aims at providing the qualified propaedeutic for technique talents in the industry [1 4].

The core of Engineering Education Accreditation, is kind of quality assessment of the matching degree between the education goals and the industry standards, to guarantee the engineering graduates access to highly recognized in the industry. In order to achieve that, the curriculum design, the teaching faculty and all sort of resources shall work for the core; and meanwhile, continuous improvement mechanism and culture is also strongly to be suggested to ensure the quality and the vigor of engineering education.

In 2006, engineering education accreditation started to be applied in realm of electricity, machinery and others, then was gradually expanded. In June, 2013, China became an associated member of the Washington Accord in the International Engineering Union Assembly held in Seoul, which accelerated the development of China engineering education accreditation. And it did significant contribution on promoting China's higher engineering education to obtain international recognition, and training more engineers who could participate in international project [5 9].

\section{Explorations of Electrical Engineering and Automation Accreditation}

Application-oriented electrical engineering and automation specialty has a close contact with practice. Therefore, comparing with other professions, it has a higher urgency to achieve the engineering education professional accreditation. Shanghai Dianji University (SDJU) launched the plan of engineering education accreditation in 2014, selected electrical engineering and automation specialty of electrical engineering institute as a pilot. SDJU attaches great importance to the accreditation project, and set up a professional team for it. In 2016, this project gained the financial aid from Shanghai Higher Education Key Teaching Reform Project. So far SDJU has achieved an initial success in the exploration research of training objectives, graduation requirements, curriculum system, practical aspects and evaluation system. 


\section{Correct Concept of Talent Training, Re-Examine the Professional Positioning, Training}

Objectives and Graduation Requirements. The concept of talent training is reflected in educational ideology and has an important influence on the talents cultivation. To conform to the current development of higher education, educators should firstly correct talent training philosophy, abandon the stereotypical ideas which no longer meet the requirements of the times, establish the concept of people-centered, holistic education and lifelong education, and focus on cultivating students' lifelong learning ability.

Professional positioning accuracy determines not only whether the students meet the market demand, but also whether the training objectives and graduation requirements is achieved. The professional talent types and the main service targets in SJDU is determined according to industry and social needs, as well as the school-running thoughts, basis, development potential and geographical features. And then electrical engineering and automation specialty sets the professional position as: adhere to the "technology-focused and application-oriented" education strategy, serve economic development of Shanghai and the Yangtze River Delta regional; persist in the student-centered educational philosophy, keep knowledge, quality, ability and overall harmonious development; cultivate application-oriented students to get the good ability of engineering technology, high humanities and professional comprehensive quality, and great development potential, which can be engaged in system operation and maintenance, engineering design and development, economic management and computer applications in the electrical engineering related field; cultivate high technique applied talents with strong innovation spirit, international cooperation and communication ability.

Graduation requirements refer to the basic requirements which should be achieved by graduate students after four years of college study. In the Washington Accord, the summary of graduation property is a group of independent and appreciable requirements, each requirement is a must-achieve quality or potential skill for graduate students ${ }^{[3]}$. And then the accreditation research team of SJDU renewed and resolved the professional graduation requirements according to the 12 items formulated by engineering education accreditation association. The team also established a relational table reflecting that graduation requirements support the training objectives, and a relationship matrix reflecting that curriculum system support graduation requirements index point.

Integrate Related Subjects and Optimize Curriculum System by Comparing Professional Norms and Engineering Education Accreditation Requirements. Core courses of curriculum system were rearranged on the basis of general education platform. And the modular curriculum system, which relying on platform core course, contains four aspects of engineering accreditation requirements and conforms to the proportion requirements. Four aspects as follows: (1) Mathematics and natural science courses (at least 15\% of the total credits); (2) Engineering basic courses, professional basic courses, professional courses (at least $30 \%$ of the total credits); (3) Engineering practice and graduation design (at least $20 \%$ of the total credits); (4) Humanities and social sciences course (at least $15 \%$ of the total credits).

Table 1 Credits percentage of curriculum system

\begin{tabular}{cccc}
\hline curriculum system & credits & $\%$ & credits hour \\
\hline $\begin{array}{c}\text { Mathematics and natural } \\
\text { science courses }\end{array}$ & 26.5 & $15.1 \%$ & 448 \\
\hline $\begin{array}{c}\text { Engineering basic course, } \\
\text { Professional basic course, } \\
\text { Professional course }\end{array}$ & 67.5 & $38.4 \%$ & 1152 \\
\hline $\begin{array}{c}\text { Engineering practice and } \\
\text { graduation design }\end{array}$ & 36 & $20.5 \%$ & \\
\hline $\begin{array}{c}\text { Humanities and social } \\
\text { sciences course }\end{array}$ & 41 & $23.3 \%$ & 656 \\
\hline Quality development & 5 & $2.8 \%$ & \\
\hline Total & 176 & $100.0 \%$ & 2256 \\
\hline
\end{tabular}


This curriculum system fully considered the proportion and seriation of each course module. Meanwhile, it also considered the matching degree of professional position, training objectives and graduate employment, so that it reflects "broad caliber, solid foundation, strong ability and high quality".

Strengthen School-Enterprises Cooperation. As a member of Shanghai Electric Group before 2013, Shanghai DianJi University has renowned industry background and natural advantages in industry resources. School-enterprises cooperation has been a unique feature of its school education. School-enterprises cooperation, combining production, industry services and characteristic development have gradually become the inner needs of talent cultivation of electrical engineering and automation.

This specialty based on objectives and features of application-oriented undergraduate education, actively explore effective mechanism of all-around, in-depth, and systematic school-enterprise cooperation with the advantages in industry background. This close cooperation relationship has been established throughout the whole teaching process, including course design, course development, teaching practice etc. The practice teaching system consists of 5 modules: experiment teaching, production practice, practice base construction, extracurricular technical practice, and extracurricular social practice. Based on deepening the existing cooperation, the specialty actively seeks for new modes of the cooperation and strives for the entire joint talent cultivation.

Establish the Evaluation Method of Graduation Requirement Achievement Integrating Internal Teaching Activity Evaluation with External Evaluation. The talents of electrical engineering and automation major are specifically trained for the realm of electrical power system and automation, power electronics and power drive and electric machinery and electric equipment. Therefore, the quality assessment needs to cover both sides of academic professionals and industry experts and employers.

The evaluation method of graduation requirement achievement combines internal teaching activity evaluation with external evaluation. It is scientific to quantitatively assess the professional ability based on the performance of every course; however, it is not enough to judge students are well-qualified from course assessment, for example for the indicators in graduation requirement such as communication, position specification, individual and team, lifelong learning and so forth. Thus, external employer evaluation and graduate evaluation are also essential which could be based on questionnaire method to check graduation requirement list then to quantify the results. The minimum values of both internal and external evaluation results are used as the final score for the achievement scale.

The evaluation of the teaching activities in school mainly through the examination results, which primary come from every point including daily record (attendance, homework and performance at seminar as examples), examination paper, internship or experiment design report, course paper, graduation dissertation and so forth. In the meanwhile, external evaluation result will be based on the statistical data of the feedbacks from graduates and employers.

The evaluation period of internal teaching activity and external evaluation system is every one year and two years, respectively. The both evaluation results and feedbacks are as the basis of revising training programs and training objectives, each index point of graduates' abilities and weight coefficient matrix of the corresponding teaching activities, to continue to improve the teaching reform and the quality of education.

\section{Conclusion}

In accordance with the technology-focused and application-oriented education strategy, and in compliance with requirements in engineering education accreditation, this article conducts an explorative research on the training objectives, graduation requirements, course structure, social practice and evaluation system in electrical engineering and automation program. The research includes the integration of related subjects, the optimization of curriculum system, the development of practice education system, and the establishment of education quality evaluation system integrating internal teaching activity evaluation with external evaluation. It will bring distinct 
improvement in the education quality of professionally accredited electrical engineering and automation specialty.

\section{Acknowledgements}

Fund Project: 2016 Shanghai Higher Education Key Teaching Reform Project "Research on the Application-oriented Undergraduate Cultivation System of Electrical Engineering and Automation under the Background of Professional Accreditation”

\section{References}

[1] Z.Y. Li: China University Teaching, Vol. 6 (2014), p.9. (In Chinese)

[2] R.F. Yang, Q. He: China Higher Education Research, Vol. 8 (2015), p.87. (In Chinese)

[3] R.P. Wang, S.Y. Wang and F.L. Li: Tsinghua Journal of Education, Vol. 1 (2015) No.2, p.34. (In Chinese)

[4] Y. Yu, X.Y. Li and C. Qin: Higher Education in Chemical Engineering, Vol. 5 (2014), p.5. (In Chinese)

[5] Y.P. Xiao: China Educational Technique \& Equipment, Vol. 3 (2014) No.6, p.82. (In Chinese)

[6] W.P. Jia: Experimental Technology and Management, Vol. 32 (2015) No.1, p.38. (In Chinese)

[7] H. Shao, X.K. Ge and H.P. Bi: Journal of Changzhou University (Social Science Edition), Vol. 1 (2014), p.104. (In Chinese)

[8] F.X. Kong, G.C. Cha and M.L. Wu: Journal of Higher Education, Vol. 18 (2015), p.65. (In Chinese)

[9] H.M. Qian, C. Li: Research and Exploration in Laboratory, Vol. 5 (2015), p.166. (In Chinese) 